\title{
Prevention of sepsis in an aging society
}

\author{
Youngjoon Kang \\ Department of Emergency Medicine, Jeju National University Hospital, Jeju, Korea
}

In recent years, Korea has very rapidly become an aging society, bringing changes that have affected many aspects of social structure. Impaired immunity and declining anatomical and physiological defenses render the elderly vulnerable to infectious diseases [1]. In addition to the expansion of the elderly population, the utilization of nursing homes and nursing hospitals has increased significantly, affecting the composition of patients and altering the role of sepsis as a cause of death. Efforts should be made to understand the distinct epidemiological features and characteristics of sepsis in each country [2-4]. During Korea's transition to an aging society, understanding the characteristics and status of sepsis in Korea will be very important for the treatment of sepsis patients [5]. The management of older patients differs from that of younger patients in antimicrobial selection and dosing, delirium management, and discussions on goals of care. Medical comorbidities, cognitive impairment, and functional status also contribute to outcomes more than age alone [6].

The median time to antibiotic administration in patients with sepsis was 2.1 hours, and the adjusted odds ratio for in-hospital mortality based on each hour of delay in administering antibiotics after registration was 1.09, even among patients who received antibiotics within 6 hours [7]. Aliyu et al. [8] suggest a high prevalence of multidrug resistant Gram-negative bacteria colonization among nursing home residents, emphasizing the need to enhance policies for infection control and prevention in nursing homes. Mody et al. [9] reported that combined technical and socioadaptive catheter-associated urinary tract infection (UTI) prevention interventions successfully reduced the incidence of catheter-associated UTIs.

The definition and treatment of sepsis have often been changed. If the definition of Sepsis and Septic Shock (Sepsis-3) is met or if the serum lactate level exceeds $6 \mathrm{mmol} / \mathrm{L}$, mortality becomes more likely and early detection requires intensive treatment [10]. Prompt detection and treatment will be important for decreasing the incidence of sepsis and reducing mortality in sepsis patients.

\section{CONFLICT OF INTEREST}

No potential conflict of interest relevant to this article was reported.

\section{ORCID}

Youngjoon Kang

https://orcid.org/0000-0002-3550-7755

Copyright () 2019 The Korean Society of Critical Care Medicine

This is an Open Access article distributed under the terms of Creative Attributions Non-Commercial License (http:// creativecommons.org/li-censes/by-nc/4.0/) which permits unrestricted noncommercial use, distribution, and reproduction in any medium, provided the original work is properly cited. 


\section{REFERENCES}

1. Liang SY. Sepsis and other infectious disease emergencies in the elderly. Emerg Med Clin North Am 2016;34:501-22.

2. Yu CW, Chang SS, Lai CC, Wu JY, Yen DW, Lee MG, et al. Epidemiology of emergency department sepsis: a national cohort study between 2001 and 2012. Shock 2019;51:619-24.

3. Quintano Neira RA, Hamacher S, Japiassú AM. Epidemiology of sepsis in Brazil: incidence, lethality, costs, and other indicators for Brazilian Unified Health System hospitalizations from 2006 to 2015. PLoS One 2018;13:e0195873.

4. Paoli CJ, Reynolds MA, Sinha M, Gitlin M, Crouser E. Epidemiology and costs of sepsis in the United States: an analysis based on timing of diagnosis and severity level. Crit Care Med 2018;46:1889-97.

5. Jeon K, Na SJ, Oh DK, Park S, Choi EY, Kim SC, et al. Characteristics, management and clinical outcomes of patients with sepsis: a multicenter cohort study in Korea. Acute Crit Care 2019;34:179-91.
6. Rowe TA, McKoy JM. Sepsis in older adults. Infect Dis Clin North Am 2017;31:731-42.

7. Liu VX, Fielding-Singh V, Greene JD, Baker JM, Iwashyna TJ, Bhattacharya J, et al. The timing of early antibiotics and hospital mortality in sepsis. Am J Respir Crit Care Med 2017;196: 856-63.

8. Aliyu S, Smaldone A, Larson E. Prevalence of multidrug-resistant gram-negative bacteria among nursing home residents: a systematic review and meta-analysis. Am J Infect Control 2017;45:512-8.

9. Mody L, Greene MT, Meddings J, Krein SL, McNamara SE, Trautner BW, et al. A national implementation project to prevent catheter-associated urinary tract infection in nursing home residents. JAMA Intern Med 2017;177:1154-62.

10. Driessen RG, van de Poll MC, Mol MF, van Mook WN, Schnabel RM. The influence of a change in septic shock definitions on intensive care epidemiology and outcome: comparison of sepsis-2 and sepsis-3 definitions. Infect Dis (Lond) 2018;50: 207-13. 